\title{
The State Security Articles of the Interior Ministry Review Prospectus at the Service of the Current Politics and the Internal Affairs Propaganda (1963-1972)
}

\section{József DEÁK}

\author{
Hadtudományi Doktori Iskola, Hadtudományi és Honvédtisztképző Kar, Nemzeti Közszolgálati Egyetem \\ Faculty of Military Sciences, National University of Public Service \\ Ludovika u. 2, 1083 Budapest, Hungary \\ yodeak@gmail.com
}

\section{Introduction}

The Ministry tried to build and strengthen the State Security Main Division III, reorganized after the 1956 revolution, with the help of internal affairs and state security propaganda methods. Between 1963 and 1972 the Interior Ministry Review played a significant role in the process by publishing international experiences in Hungarian. However, the selection and edition of the articles often carried obvious background content or messages. Their deductions are not always valid only for the contemporary era; some may be valid even today. This is the first time this topic has been researched.

\section{The foreign, interior political and policy context}

Following the 1956 revolution, the consolidation of the domestic political situation was given a new impetus in this period.

"What made possible the Hungarian People's Republic's breaking out of the 'political quarantine' was that as a result of the negotiations that began in 1960 the so-called 'Hungarian issue' was withdrawn from the agenda of the United Nations (UN) in December, 1962. As a direct result, most of the '56ers' were granted a general amnesty in March 1963. ... "1 However, in the calming, re-establishing domestic political situation the Interior Ministry (abbreviated to BM in Hungarian) needed to be strengthened, reorganized and adjusted to the new circumstances:

"The new structure, formed at the beginning of the 1960s (the earlier system of departments were replaced by a system of main divisions, divisions, separate departments, departments and sub-departments), did not leave untouched the organizations responsible for providing information either." 2

The interior propaganda, popularizing the Interior Ministry's activities trying to persuade wide sectors of the society for the Ministry's tasks, had to be updated. The press releases

\footnotetext{
1 Miklós M. SZABÓ, A Zrínyi Miklós Katonai Akadémia története 1961-1969, Budapest 2008, 13.

2 Trezor 3. Az átmenet évkönyve 2003, György GYARMATI (ed.), Sorozatszerkesztő Kónyáné dr. Kutrucz Katalin, Budapest 2004, 148.
} 
issued by the Ministry itself were the most determinative in this field.

With regard to all these, the College of the Interior Ministry held a consultation on the report covering the analysis of the professional level of the Interior Ministry's press releases and journals in April 1962 concluding that "... the effective fulfilment of the Ministry's tasks has to be better facilitated with the help of the press." 3

The Interior Ministry Review, as the central journal of the Interior Ministry, during its 60 years of existence was always regarded as leading in covering jurisdiction and law enforcement in a professional way as was stated at its memorial conference at the Interior Ministry. ${ }^{4}$ Part of the above mentioned series of measures of the Interior Ministry College was a periodical, issued quarterly between 1963 and 197215 times, entitled "Interior Ministry Review Prospectus" or "Foreign Observer", classified as "for service use only". Relying on the available, more or less comprehensive foreign collection of journals, the editorial of the Interior Ministry Review published the periodical for those "wishing to realize scientific needs in their theoretical or practical work." 5

The journal was published in order to provide the leaders of the Interior Ministry and its permanent authors with information "regarding up-to-date information about the Interior Ministry's departments, major issues that foreign police forces have had to deal with."6 Typically by translating articles of foreign, "capitalist" journals. The review of the interior journals of the "socialist block", including the translation of some interesting articles was classified as "for service use only", later "for interior use only" but was openly distributed.

\section{About the State Security in details}

In this section we will take a look at some material connected to certain countries' state security and secret service organizations, actions and professional solutions.

\section{I/a. Political attacks and... messages?}

The series of state security articles was opened by an extract made from the book "Das Attentat" by Hans Langemmann, published 1956 (!) in Hamburg. The book, as it turns out from its short review "... analyses political attacks against heads of state and political persons trying to reach scientific findings."7

The choice of subject might not have been accidental as after the retaliations following the 1956 revolution such responses were expected. The article may reflect the fear emerging in the new leaders and at the same time intensified the alertness of the ones entrusted with

3 József DEÁK, Az állambiztonsági propagandától a nemzetbiztonságig - a Belügyi Szemlében megjelentek tükrében, in: Rendvédelem, a Belügyminisztérium Oktatási, Képzési és Tudományszervezési Főigazgatóság online folyóirata, 2013/3, 20.

4 József DEÁK, Hatvanéves a Belügyi Szemle, 2013/1-3, 15, in: Rendőr, Az ORFK Szóvivői Iroda, Belső szakmai Intranetes lapja (Internal police sealed access password-protected professional website),

https://intra.police.hu/sites/default/files/2013_01-03_RENDOR.pdf (Visited: on 27 May 2014).

5 Belügyi Szemle Tájékoztatója (Kiadja a BM Tanulmányi és kiképzési Csoportfőnöksége), 1963/1-2, 3.

6 lbidem.

7 A politikai merényletek vizsgálata bűnügyi tudományos szempontból, in: Belügyi Szemle Tájékoztatója, 1963/12, 30-32. 
their guarding as well as trying to justify with the choice of subject that it is well-founded and educational to follow the Western-European experiences.

The article, reviewing a few chapters, shows the author's points of view and the evaluation of the 52 political attacks he chose to analyse. He grouped the perpetrators and analysed the implementation techniques. Following the description of attacks using poison, stabbing or fire weapon and some historical examples, while illustrating attacks using explosives the author provides a detailed description of "the successful attack against Heydrich SS leader, the governor of the Czech-Moravian Protectorate on 27 May 1942 and two of the unsuccessful ones against Hitler (8 November 1939 and 20 July 1944)", carefully examining the positive and negative effects of the circumstances.

The article, appearing in the first, double issue of the Review, does not forget to show the moral of the book either, describing what the author thinks of the handling of the attacks. "To this end, he considers such a state leadership necessary that dampen differences in the society as much as possible and ... does not create a hopeless social class and on the other hand a police force where the evaluation of the intelligence materials and taking the appropriate actions are in line." 8

In 1963, between the lines this article in the Internal Ministry Review did not only support and justify the principle of the new party leader, János Kádár at the beginning of the 1960s, which allowed "the more uninterrupted life of the silent majority (the non-active opposition)". 9

His principle was "He who is not against us is with us". The article also takes sides about the direction of the state leadership in some respects. Following a reference to an attempted attack against Adenauer in 1952, the compulsory criticism of the investigating organizations of the FRG (Federal Republic of Germany) can be found: "None of the bodies possess the necessary intelligence network, some of them lack the necessary executive body. The different police bodies rival with each other and besides this, there is jealous competition between the police and military forces acting on political cases." 10

In the later versions of the principles governing the interior propaganda, the specific need can be found, which, in its most advanced form, will be the first documented principle of the propaganda work for the security of the state: "a) it is expected to present and unveil the scandals of the CIA and other imperialist organizations, the relations of interest between the hostile intelligence, security and certain individual economic and other interest groups; the internal fights of hostile intelligence and security organizations and their fights with each other." 11

The quoted thought, maybe not incidentally, may refer to the necessity of the above mentioned reorganization taking place at the Interior Ministry at the beginning of the 1960s.

8 Ibidem, 32.

9 SZABÓ, 2008, 12.

10 A politikai merényletek vizsgálata bűnügyi tudományos szempontból, in: Belügyi Szemle Tájékoztatója, 1963/1-2, 32.

11 Állambiztonsági Szolgálatok Történeti Levéltára (Historical Archives of the Hungarian State Security), 4.2.2. Series, Box No. 31. A BM külső - a lakosság körében végzendő - propaganda munkájának 77-80 évekre szóló irányelvei, 28 March 1977, 12. 


\section{I/b. The FBI's motto}

It is not in the category of the state security articles but the material entitled "When, how and why does the Federal Bureau of Investigation (FBI) intervene?"12 certainly belongs here. Its original English title was kept as well, presumably for educational purposes.

The first two articles of the first issue in 1964 deal with the United States, the first one describing the jurisdiction (in which the polygraph, the "lie detector" and its use in recruiting police officers ${ }^{13}$ is first mentioned in Hungary), ends with the short introduction of the FBI, ${ }^{14}$ almost making way for the next one, to be introduced now.

It reveals that the "humble organization", formed in 1908 under Theodore Roosevelt's presidency, was created to watch out for the breaking of the Anti-trust Law and to carry out secret federal investigation like the case of infringement of the far-western lands, in cooperation with the government offices. ${ }^{15}$

Secret investigation made people think of an espionage system, which was almost true as the Bureau got this task as well during WWI, to investigate the opportunities of the German spy ring. The 400-people organization was finally given more authority after the 1917 Russian revolution; it was formed into a more serious, more solid one, especially in the long decade under the leadership of Edgar Hoover from 1924. Its actions against the intensifying organized crime following the 1929 economic crisis further strengthened the organization, the 23-41 years old members of which had to possess laws doctoral or equivalent degree.

The FBI, the slogan of which is "Fidelity - Bravery - Integrity", first stood for the wrongly accused as well; in 1952 it requested the acquittal of a person accused of cheque fraud. This thought must have been something to consider for the domestic, especially political but also ordinary investigating bodies of the time.

\section{I/c. Counter-Intelligence under a Democratic Rule of Law}

The following translation entitled "Measures to prevent foreign intelligence organizations' attempts to make contacts"16 appeared in the 1966 issue.

In retrospect, its findings would have been useful in the "secret service" system change and are useful even today. The article of the German military journal "Truppenpraxis" entitled "Counter-intelligence under a democratic rule of law" starts with the following sentence: "Only this regime is able to fully seal military power and related things from the outer world. This method certainly makes counter-intelligence a lot easier." 17

The rest of the article reveals that even if many people think the press publishes everything, the parliamentary decisions and the communications of the National Defence Ministry and

\footnotetext{
12 Belügyi Szemle Tájékoztatója, 1964/3,

13 DEÁK, Hatvanéves a Belügyi Szemle, 15.

14 Belügyi Szemle Tájékoztatója, 1964/3, 5.

15 Ibidem, 8.

16 Belügyi Szemle Tájékoztatója, 1966/5, 35-39.

17 Ibidem, 35.
} 
other official bodies can not be treated as secret because "... We, soldiers do not wish to live in a security ghetto at all. We consciously enjoy our democratic civil rights. We are aware that in our state system the security service faces difficult problems. But because we support it, we consciously have to deal with these difficulties and fight them... We do not want to be excluded from the society of our own people by exaggerated secrecy. On the contrary!"18

Because of their fight against hostile intelligence agencies they really had to focus on things kept secret (new weapons, devices, secret things). While there are a few of these things at the corps, the higher commands have a lot more of them: "... it is possible to find the right relation to the press as well. It is up to us to continuously make it more and more pleasant and then press representatives will understand that certain things can not be published because of secrecy." 19

Then it turns out why only the commander of the press officer can inform the press: "Because an ordinary soldier is mostly unable to decide where the boundary is between confidential and open communication." 20

In the following the article emphasises under separate titles the topics of the cooperation between preventive counter-intelligence, financial prevention, personal prevention and military preventive services; how a suspicious case can be identified, in which forming a relationship of trust between the officer and the fighter is considered important. In the case of suspicion the members of the preventive force should be notified. One of the closing statements of the study is "The enemy will possess as much power as we let them have." ${ }^{21}$

\section{I/d. Soviet state security bodies in WWII}

We come across the following state security article in the "Political and general articles" section of the 1968/7 issue of the Review. It is entitled "Thoughts about the operation of the Soviet state security services, of their fight against hostile intelligence and commandoes on the Soviet-German front during WWII."22

Its author is Laszlo Fekszi, lieutenant-colonel, but it is possible that he only reviewed a longer study. Following the then compulsory ideological details he describes what a wide intelligence network Nazi Germany was building in preparation to attack the Soviet Union, especially along the borders while during the summer of 1942 the German security bodies admitted that the German intelligence did not have precise information on all levels about the country and its forces. ${ }^{23}$

According to the article, not lacking the contemporary ideology: "What played the great-

18 József DEÁK, Az állambiztonsági propagandától a nemzetbiztonságig - a Belügyi Szemlében megjelentek tükrében, Rendvédelem, a Belügyminisztérium Oktatási, Képzési és Tudományszervezési Főigazgatóság online folyóirata, 2013/3, 6.

http://www.rvki.hu/images/downloads/rentudfoly/2013.\%20vi\%203.\%20szm.pdf letöltés 07.10.2013.

19 Belügyi Szemle Tájékoztatója, 1966/5, 35-36.

20 Ibidem, 36.

21 Ibidem, 39.

22 Belügyi Szemle Tájékoztatója, 1968/7, 15-19.

23 Ibidem, 16. 
est role in the interruption of the secret war and the crushing of the Nazi army was the existence of the socialist state..." 24 The economic and human potential of the country is not mentioned just like the expression "the unshakable trust of the civilian population in the homeland" 25 has a different meaning today, with knowledge of the existence of the gulags. The article reveals that the Soviet state security services fought not only the German but also the Japanese, Turkish and the allied American and British (!) intelligence forces. Besides the Soviet security services, the study devotes space to offensive activities of the intelligence, like the organization of the partisan movement. As a conclusion, the author emphasizes the continuous use of the experiences of the Great Patriotic War because "as a result of our duties specified in the Warsaw Pact, the imperialist intelligence bodies are actively carrying out intelligence activities against the Hungarian and the temporary Soviet forces... Some western military leaders and right-wing politicians regard the policy of peaceful coexistence as the weakness and permissiveness of the Hungarian People's Republic. Under the cover of tourism, during the in and outward travels they try to recruit people to perform anti-state activities." 26

These two statements reflect well the inconsistency and duality of the contemporary international political system. The bipolar world's fierce opposition, despite the forming of "peaceful coexistence", in which in 1968 even the armed intervention of the Warsaw Pact countries' - Soviet, Polish, Eastern-German, Hungarian and Bulgarian - troops against Czechoslovakia (21 August) was possible. ${ }^{27}$

\title{
I/e. About the German Secret Service in a different way
}

The following material belongs to the state security topic in the Foreign Observer of the Interior Review; it is about Germany, too: an article on the leader of the Gehlen organization $^{28}$ by Ferenc Barta police major, who possibly used the articles of foreign journals mentioned in the foreword.

Its publication in 1969 may reflect well the process by which the western part of Germany regained its strength and acquired international prestige.

By the 1970s the Federal Republic of Germany (FRG) "is not only an economic but also a trade and financial power, besides, it possesses the strongest army of traditional weaponry in Western Europe."

The article, having reviewed the fight of the "Nazi German intelligence" against the Soviet Union during WWII, gives an overview of the evolution of the German secret services by describing the life of Reinhardt Gehlen, leader of the West-German Secret Service for 26 years. $^{29}$

From the birth of the contemporary German secret service we get to the structure of the

\author{
24 Ibidem \\ 25 Ibidem, 17. \\ 26 Ibidem, 18. \\ 27 SZABÓ, 2008, 8. \\ 28 Belügyi Szemle Tájékoztatója, 1968/9, 79-83. \\ 29 Ibidem, 79.
}


Federal Intelligence Service of the FRG, to the detected activities against the socialist and the neighbouring capitalist countries.

The translation of a book review, published in the $12^{\text {th }}$ issue of the Foreign Observer in 1971 is about the German Secret Service as well. Its title is "All need to be known about the Abwehr" and reviews the latest published work of Dr. Julius Mader, ${ }^{30}$ an internationally recognized expert on the history of western secret services.

The book is about the intelligence and counter intelligence corps of the Supreme Command of the Armed Forces (OKW) based on the testimonies of Hitler's intelligence generals, providing details about the history, activities and methods of the Abwehr.

The last article about the west-German secret service was published in the $14^{\text {th }}$ issue of the studies series of the Foreign Observer, entitled "An insight into the work methods of the Constitutional Protection Bureau". ${ }^{31}$

During a trial the court would like to call one of the agents at the Constitutional Protection Bureau but the Interior Senator, who is responsible for the operation of the Bureau, restricts his permissions to testify and thus limits the rights of the defence. In connection with the case, the journal Der Spiegel made an interview with Kurt Neubauer, the Interior Senator. The article is a good example of how smartly the Bureau is able to defend its public and secret elements of its statutory work even in public.

\section{Secret services during the total cold war}

"The foreign policy situation of the 1970 - despite all fluctuation - provided a considerably more balanced and peaceful atmosphere for humanity than the previous decades." 32

However, the total cold war still goes on and is kept going on in writing and in the air. This is reflected by the two translations first published under the "Intelligence - counter-intelligence" column in the $11^{\text {th }}$ issue of the Review at the end of 1970.

The first is about "The commandoes of the cold war" 33 and tells the story of the trainings, missions, deployment and capture of a Russian speaking spy group sent into Belarus (Soviet Union) in 1953, Estonia in 1954 and Lithuania the following year. The story is based on the interview made with one of the members, who gave himself up voluntarily.

\section{II/a. The birth of a spy group}

The article tells the story of an engineer in the occupied Belarus in 1942, called Kaminski, who contacted the German authorities and offered to create a group out of the local people to fight against the partisans. The Germans accepted the offer. The men of Kaminski showed such abilities during the voluntary tasks that in no time the group turned into an SS brigade and - which was unprecedented - was given permission to govern the territory under their control in an "autonomous" way. For a while Kaminski was lord of life and

30 Belügyi Szemle Tájékoztatója, 1971/12, 37-39.

31 Belügyi Szemle Tájékoztatója, 1972/14, 26-28.

32 Miklós M. SZABÓ, A Zrínyi Miklós Katonai Akadémia története 1970-1979, Budapest 2010, 5.

33 Belügyi Szemle Tájékoztatója, 1970/11, 53-58. 
death in his territory. But the ex-engineer went so mad with power that he occasionally took arbitrary actions against his own masters and looted the Germans' property. Kaminski and some of his men were executed, the rest of his squad was assigned to two different divisions, the commander of which became Andrey Vlasov, the soviet general who defected to the Germans.

The interviewee, a spy named Chmelnitski, was mobilized into Kamiski's squad in 1942, during the German occupation and then, as described above, he was moved to Vlasov's first division. At the end of the war, being afraid of the Soviet authorities, he fled to the American occupation zone. He was sent to an American camp where, after the signing of the Potsdam Agreements, he learned that all POWs were about to be transported back to the Soviet Union. So he escaped from the camp and joined the "resettlers" near Munich. He then describes in short what jobs he tried to do, in a Belgian mine from 1948 and then in a French factory.

While working in a chemical factory, one evening a Russian priest dressed in plain clothes, named Leonid Nikolski came to find him in his apartment. He told him that he was a member of the west-German immigrant anti-soviet organisation, the NTS (Narodni Trudovoi Soyuz - Working People's Association) and he was recruiting for the successfully fighting organisation that even had a program and he had heard of Chmelnitski, that is why he came to find him. He promised and did send him some brochures and journals of the organization. These showed that its aim was to overthrow the Soviet system.

A month later Chmelnitski was contacted by another countryman of his who, after short talks, told him that as he was politically weak, he had to go to Bad Hamburg, near Frankfurt, to take part in a training at the research institute of the NTS.

They had a German visa made for Chmelnitski and he travelled to Bad Hamburg where he was welcomed by Okolovits, one of the local leaders of NTS.

He learnt topography, the basics of illegal life, shooting and the making of forged documents at the Institute, which was often visited by spies living in West-Berlin but working in East-Berlin. Americans arrived too, officers of the intelligence centres, who corrected the exercises and helped in the training.

In June 1952, Okolovits called Chmelnitski among others, telling them that their organisation needed cadres able to operate in Soviet territory. They asked the Americans to help train them. He told them they would be sent to the Soviet Union soon. The chosen 8-member group was first taken to Munich where the Americans interrogated the candidates using lie detectors in private apartments. This was followed by a one-week examination in a hospital. Soon they were taken to a villa near Munich where two Russian and two Russian speaking American agents taught them their new identities. In the end they were made to sign a non-disclosure agreement - the breaking of which would have meant being court-martialled. During the following days they practised close combat and shooting. They studied how to operate a radio, encrypt messages, forge documents, studied different types of Soviet weapons, the activities of the Soviet authorities, practised the rules of illegal life like travelling at night using a compass etc. They started learning and practising parachuting in the seventh month, day and night.

At the end of the nine months spent there, their training was considered sufficient in April 1953 and they were assigned to three groups. 


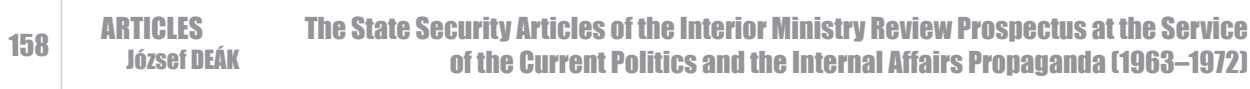

The group of Chmelnitski was dropped from an American four-engine military aircraft above some forests in Belarus. After landing, they went straight to a Soviet police station.

\section{II/b. Spy techniques}

The following, "In the world of total espionage" 34 , was published on 14 August, in the 1970 issue of Novoe Vremia, the Soviet political weekly.

It explores the application of the achievements of the "western scientific-technical revolution" by intelligence organizations and other methods. The article about the "all-seeing eye" first explores the countless fields of the activities of industrial espionage, with special attention to the cutting edge economical sectors like the nuclear, electrical, chemical, pharmaceutical, petroleum and automobile industry. The article also mentions all-hearing devices, "mini-spies" and those hunting for garbage and human souls. Dealing with industrial espionage, the article enumerates the possible ways of protection against it.

\section{II/c. Ideological means and methods}

The following writings show one of the main aspects of the cold war: the ideological war, presenting its general and specific sides. According to the article entitled "In the service of Zionism and the imperialist intelligence" 35 "the reactionist circles of the United States of America widely and actively use the Zionist centres of the political diversion... in order to delay and prevent the powers of socialism from evolving." ${ }^{36}$

The editors of the Review chose the remaining two articles on the basis of this rather one-dimensional, low-value style from a state security point of view: "About the disruptive work of the imperialist intelligence bodies" ${ }^{37}$ and "The present and future of the Free Europe and Freedom radio stations". ${ }^{38}$

\section{Conclusion}

The Interior Ministry Review tried to meet the current expectations of the interior state security propaganda as well, as it was expected from the central journal of the Ministry. In the studied Reviews of ten years, besides the foreign articles selected mainly along ideological viewpoints, there can also be found a majority of high quality articles of deep professional value, carrying messages for the present as well.

\section{Abstract}

The structure of the state security services, operating within the organization of the Interior

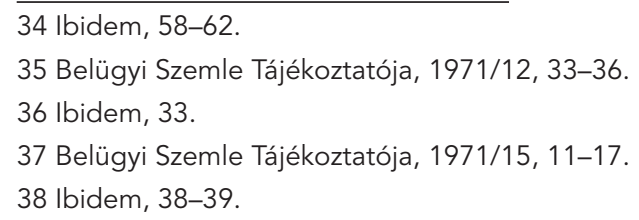


Ministry, was radically reorganized after the 1956 revolution, similarly to that of the ministry. The Ministry tried to strengthen the quasi newly created state security organization, the State Security Main Division III with the help of internal affairs and state security propaganda methods. What role did the Interior Ministry Review prospectus have in this process between 1963 and 1972? What international experience and articles were chosen to extensively and intensively develop the organization? What methods, solutions and messages of the internal and allied state security propaganda are conveyed by these translations? What, possibly even current and useful professional ideas, solutions, advice or deductions do these writings contain? What domestic or international political backgrounds or situations are reflected by these articles?

\section{Keywords}

Interior Ministry, State Security, the Interior Ministry Review, Interior Propaganda

\section{References}

Állambiztonsági Szolgálatok Történeti Levéltára (ASTL)

Historical Archives of the Hungarian State Security:

Series 4.2.2, Box No. 31

Belügyi Szemle Tájékoztatója, 1963/1-2.

Belügyi Szemle Tájékoztatója, 1964/3.

Belügyi Szemle Tájékoztatója, 1966/5.

Belügyi Szemle Tájékoztatója, 1968/7.

Belügyi Szemle Tájékoztatója, 1968/9.

Belügyi Szemle Tájékoztatója, 1970/11.

Belügyi Szemle Tájékoztatója, 1971/12.

Belügyi Szemle Tájékoztatója, 1972/14.

Belügyi Szemle Tájékoztatója, 1971/15.

DEÁK, József: Hatvanéves a Belügyi Szemle, in: Rendőr ORFK Szóvivői Iroda Belső szakmai Intranetes lapja, 2013/1-3, 15. https://intra.police.hu/sites/default/files/2013 01-03 RENDOR.pdf (Visited: on 27 May 2014).

DEÁK, József: Az állambiztonsági propagandától a nemzetbiztonságig - a Belügyi Szemlében megjelentek tükrében, in: Rendvédelem, a Belügyminisztérium Oktatási, Képzési és Tudományszervezési Főigazgatóság online folyóirata, 2013/3, 15-22.

GYARMATI, György (ed.): Trezor 3. Az átmenet évkönyve 2003, Sorozatszerkesztő Kónyáné dr. Kutrucz Katalin, Budapest 2004.

SZABÓ, Miklós M.: A Zrínyi Miklós Katonai Akadémia története 1961-1969, Budapest 2008.

SZABÓ, Miklós M.: A Zrínyi Miklós Katonai Akadémia története 1970-1979, Budapest 2010. 